\title{
ANALISIS TEKNOLOGI PENGEMBANGAN PRODUK PANGAN PENGGANTI TERIGU MENGGUNAKAN Modified Cassava Flour (MOCAF) DI WILAYAH KABUPATEN BANYUMAS, JAWA TENGAH
}

\section{Analysis of Technology for The Development of Wheat Replacement Food Using Modified Cassava Flour (Mocaf) in Banyumas, Central Java}

\author{
Slamet Sulistiadi \\ Teknik Pertanian dan Biosistem, Universitas Nahdlatul Ulama Purwokerto \\ Korespondensi penulis, Email: sulistiadislamet22@gmail.com
}

\begin{abstract}
Modified Cassava Flour (MOCAF) is flour with modified starch content from cassava whose quality has been tested to substitute products derived from flour. The opportunity to use MOCAF as a substitute for flour in Banyumas Regency is very high because the manufacturing process technology is simple, and the number of flour processed product industries in the Banyumas Regency is huge. The purpose of this research is to conduct a feasibility study to determine the appropriate technology in the process of making a Lactic Acid Bacteria starter for MOCAF and to determine the appropriate technology in the storage process of cassava raw materials, the chopping process and fermentation of cassava. The process of assessing the feasibility of technology is carried out using the Systems Approach method using a production systems approach. The results of the study indicate that the MOCAF processing stage includes the preparation stage of making a starter, preparation and storage of cassava raw materials, chopping process, and fermentation process. The Banyumas community can implement the development of MOCAF because the use of technology is user-friendly.
\end{abstract}

Keywords: mocaf, wheat, technology, systems, banyumas

\begin{abstract}
ABSTRAK
Modified Cassava Flour (MOCAF) merupakan tepung dengan kandungan pati termodifikasi dari Singkong yang kualitasnya sudah teruji untuk mensubtitusi produk turunan dari terigu. Peluang pemanfaatan MOCAF sebagai pengganti terigu di Kabupaten Banyumas sangat tinggi, karena teknologi proses pembuatannya sederhana dan jumlah industri produk olahan terigu di Kabupaten Banyumas sangat banyak. Tujuan penelitian ini melakukan studi kelayakan untuk menentukan teknologi yang tepat dalam proses pembuatan starter Bakteri Asam Laktat untuk MOCAF dan dapat menentukan teknologi yang tepat dalam proses penyimpanan bahan baku singkong, proses pencacahan dan fermentasi singkong. Proses penentuan kelayakan teknologi dilakukan menggunakan metode Systems Approach dengan menggunakan proses pendekatan sistem produksi. Hasil pengkajian menunjukkan bahwa proses pengolahan MOCAF dari tahap persiapan pembuatan stater, penyiapan dan penyimpanan bahan baku singkong, proses pencacahan, dan proses fermentasi. Pengembangan MOCAF dapat diimplentasikan oleh masyarakat Banyumas karena penggunaan teknologinya sangat sederhana.
\end{abstract}

Kata kunci: mocaf, terigu, teknologi, sistem, banyumas 


\section{PENDAHULUAN}

Impor gandum Indonesia hampir mencapai 8,5 juta ton di tahun 2016 (Ridha, 2016). Ketergantungan impor gandum oleh pemerintah Indonesia dapat diatasi dengan substitusi menggunakan tepung yang berasal dari sumber karbohidrat lokal. Penelitian pemanfaatan karbohidrat lokal sebagai tepung pertama kali diteliti oleh Pangloli dan Rojangsih (1998) yang menggunakan sagu sebagai bahan tepung. Tepung-tepungan yang berasal dari sumber lokal seperti tepung sukun (Meliani, 2002), tepung sorgum (Suarni, 2004), tepung biji nangka (Prabandari, 2008) dan tepung kimpul (Ermiza, 2010) diteliti lebih lanjut dan menghasilkan tepung yang memiliki partikel kasar dan keras (Jading, 2011). Selain itu, menurut penelitian yang dilakukan tepung-tepung pengganti terigu tersebut hanya digunakan sebagai komposit terigu tidak dapat menggantikan 100 \%. MOCAF (Modified Cassava Flour) yang berbahan dari singkong adalah penemuan yang dilakukan oleh Ahmad Subagio (2007) dianggap berhasil mensubstitusi tepung terigu pada beberapa produk-produk turunannya mencapai 100\%. MOCAF diketahui juga memiliki kualitas setara dengan tepung terigu sehingga bisa berkembang sampai pada tahap industrilisasi.

Industri produk olahan terigu di Banyumas berkembang cukup pesat. Toko Bakery sebagai pelopor produk olahan dari terigu di Indonesia berdiri pertama kali di Purwokerto. Produsen-produsen olahan terigu yang lain di Banyumas sudah memiliki jangkauan pasar tingkat nasional bahkan pasar ekspor seperti produk Roti Ramona. Beberapa Industri lain di Banyumas memiliki rata-rata penggunaan terigu yang tinggi seperti industri mie, soun, roti, snack dan industri makanan tradisional membutuhkan terigu hampir 60 ton setiap hari. Berdasarkan potensi kemampuan MOCAF untuk mensubstitusi terigu maka kondisi tersebut sangat penting untuk diperhitungkan dalam mengembangkan usaha MOCAF sebagai pengganti terigu. Singkong sebagai bahan baku MOCAF juga merupakan komoditas penting pendukung sistem ketahanan pangan yang banyak tumbuh di Banyumas.

$$
\text { Terwujudnya pengembangan }
$$
produk pangan MOCAF sebagai pengganti terigu perlu memperhatikan aspek teknologi proses yang digunakan. Semenjak MOCAF dipublikasikan oleh Subagio (2007), riset tentang MOCAF banyak berkembang dari skala Laboratorium menjadi skala UKM bahkan Industri besar. Penelitian ini bertujuan menentukan teknologi yang tepat dalam proses pembuatan starter Bakteri Asam Laktat untuk MOCAF dan menentukan teknologi yang tepat dalam proses penyimpanan bahan baku singkong, proses pencacahan dan fermentasi singkong. Penentuan teknologi proses pengolahan MOCAF yang paling tepat dikembangkan di Banyumas berdasarkan 
data yang diperoleh melalui penelitianpenelitian MOCAF skala laboratorium ataupun teknologi pengolahan MOCAF dalam skala industri kecil. Teknologi yang tepat dapat diketahui dengan mengkaji dan mengelompokkan proses pengolahan pembuatan starter bakteri, penyimpanan bahan baku, pencacahan dan fermentasi yang kemudian output dalam proses pengolahan tersebut dibuat ke dalam neraca perbandingan waktu, energi dan biaya.

\section{METODE PENELITIAN}

\section{Observasi}

Observasi dilakukan dengan membuat MOCAF secara langsung dalam skala laboratorium dengan mengikuti referensi yang ada. Pembuatan starter skala laboratorium dengan menggunakan metode yang diterapkan Handayani (2006), Rachman (2016) dan Sulistiadi (2015). Proses penyimpaanan bahan baku singkong menggunakan metode Ginting (2002). Sedangkan Proses pencacahan, fermentasi, mengunakan metode yang diterapkan Sulistiadi (2015).

Observasi juga dilakukan dengan kunjungan ke Industri MOCAF skala UKM (Usaha Kecil Menengah) yang dilakukan oleh Ibu-ibu kelompok tani di Banjarnegara untuk mengamati proses pembutan starter, penyimpanan Singkong, prses pencacahan, dan fermentasi. Selain itu pengamatan pada proses penyimpanan Singkong juga dilakukan di petani
Singkong, industri Tapioka, penjual Singkong di pasar.

\section{Wawancara}

Data wawancara diperoleh dari buruh petani singkong, pemilik lahan singkong, penjual singkong di pasar, produsen MOCAF, dan Dinas Perindustrian dan Perdagangan Kabupaten Banyumas. Informasi yang diperoleh dalam wawancara adalah sebagai berikut:

1. Informasi terkait teknologi penyimpanan pasca panen singkong, pengolahan pasca panen singkong diperoleh berdasarkan wawancara dengan buruh petani singkong, pemilik lahan singkong dan penjual singkong di pasar

2. Informasi terkait teknologi pengolahan MOCAF dan pengembangannya diperoleh melalui wawancara dengan produsen MOCAF dan dinas perindustrian dan perdagangan Kabupaten Banyumas

\section{Studi Literatur}

Studi literatur dilakukan agar penyusunan dalam penelitian sistematis. Studi literatur dilakukan pada buku-buku, jurnal dan penelitian yang telah dilakukan yang berkaitan dengan MOCAF, teknologi pengolahan Singkong dan membahas tentang Biosystem Engineering.

\section{Analisis Data}

Data yang sudah diperoleh dianalisis menggunakan Metode Approachs System 
Analysis (Alocilja, 2008) . Dimana proses pengolahan MOCAF dikaji sebagai suatu sistem produksi yang dilakukan berdasarkan skala laboratorium dan skala UKM. Dalam sistem produksi MOCAF dibagi menjadi dua sub sistem utama yaitu sub sistem pembuatan starter bakteri, sub sistem penyimpanan bahan baku, pencacahan dan fermentasi. Masingmasing sub sistem memiliki komponen yang lebih kecil yaitu komponen input, proses dan output. Selanjutnya penentuan teknologi yang tepat yang dapat digunakan di industri MOCAF Banyumas dilakukan dengan membuat neraca waktu, energi dan biaya sebagai perbandingan pada setiap proses.

\section{HASIL DAN PEMBAHASAN}

\section{Pembuatan Starter Bakteri Asam Laktat}

Pembuatan starter skala laboratorium menggunakan metode Rachman (2016) sebagai komponen input dalam sub sistem pembuatan starter membutuhkan peralatan laboratorium yang cukup lengkap. Beberapa bahan yang dibutuhkan antara lain Bakteri Asam Laktat (BAL), susu skim, susu murni, air suling, natrium hidroksida, asam sulfat fenoflatein, glukosa dan laktosa. Sedangkan dalam komponen proses, prosedur pembuatan starter dilakukan melalui proses pasteurisasi pada susu murni, sterilisasi pada media botol dan inkubasi selama 24 jam pada ose BAL, dan inkubasi kembali pada suhu $37^{\circ} \mathrm{C}$ selama 24 jam.
Komponen output pada pembuatan starter BAL skala laboratorium berdasarkan neraca waktu membutuhkan waktu sekitart 3-5 hari dan membutuhkan daya energi standar laboratorium penelitian sekitar 23.000 VA. Biaya yang digunakan dalam pembutan starter BAL sangat tinggi dan membutuhkan penanganan laboratorium yang tidak sederhana.

Metode yang diterapkan Sulistiadi (2015) menggunakan Asam laktat praktis sebagai pengganti starter. Dalam komponen input skala laboratorium bahan yang diperlukan dalam persiapan stater hanya Asam laktat praktis. Sedangkan komponen proses dalam penggunaannya bisa langsung digunakan tanpa membutuhkan perlakuan laboratorium khusus. Komponen input pada neraca waktu diketahui sangat cepat karena bisa langsung digunakan setelah pembelian. Begitu juga pada neraca energi, penggunaan Asam laktat praktis hanya membutuhkan energi yang sangat kecil. Sedangkan pada neraca pembiayaan penggunaan Asam laktat praktis membutuhkan biaya yang sangat tinggi dengan harga Rp 20.000,00 per $35 \mathrm{ml}$.

Komponen input yang dilakukan Sulistiadi (2012) dalam pembuatan starter BAL membutuhkan susu skim, kacangkacangan, dan air leri. Komponen proses diawali dengan membuat kultur stok menggunakan susu skim yang telah dipasteurisasi. Setelah itu membuat stater menggunakan air leri dan kacang- 
kacangan sebagai sumber makanan dari BAL. Air leri dan kacang-kacangan sebelum dicampur dengan kultur stok direbus dahulu dengan pemanasan biasa. Kultur stok ditambahkan setelah starter dingin. Dalam komponen output di neraca waktu, proses pembuatan starter dengan metode ini hanya membutuhkan waktu 2 hari. Sedangkan energi yang diperlukan sangat kecil karena dapat dilakukan dalam skala rumah tangga. Sedangkan biaya yang dibutuhkan dalam proses pembuatan starter terjangkau, karena bahan dan alat mudah dicari serta didapatkan.

Skala UKM pembuatan starter yang dilakukan kelompok tani Ibu-ibu dalam komponen input. Dapat diketahui bahwa bahan starter yang digunakan dalam tiga bentuk, yaitu menggunakan ragi tape padat, stater bantuan dari Dinas Pemerintah dan starter yang dibeli melalui toko-toko online. Ukuran penggunaan stater pun tidak ada ketentuan khusus hanya berdasarkan pada perkiraan saja. Pada komponen proses starter yang diperoleh langsung digunakan sebagai bakteri perombak granula pati Singkong. Komponen output yang didapat pada neraca waktu adalah satu hari dengan energi yang dibutuhkan kecil. Sedangkan pada neraca pembiayaan diketahui bahwa harga stater ragi tape termasuk mahal, karena harganya melebihi harga singkong sebagai bahan baku MOCAF. Komponen penting yang perlu diketahui adalah hasil proses pengolahan MOCAF menggunakan starter ragi tape dan starter dari pemerintah ataupun starter online didapat MOCAF yang tidak baik kualitasnya. Karena proses fermentasinya tidak menggunakan starter yang tepat dan jelas. Starter ragi tape diketahui menggunakan bakteri yang menghasilkan Alkohol bukan asam laktat (Subagio, 2007) jika difermentasikan dengan pati singkong,. Sedangkan starter yang didapat oleh Dinas Pemerintah diakui oleh para produsen MOCAF skala UKM sangat sulit keberlanjutannya karena ketersediaan starter yang terbatas. Seperti halnya dengan starter yang dibeli secara online kebenaran mengandung BAL tidak dapat dipertanggungjawabkan secara pasti. Hasil analisis perbandingan neraca waktu, energi dan biaya dicantumkan dalam Tabel 1.

Tabel 1. Perbandingan Neraca Waktu, Energi dan Biaya pada Komponen Output Sub Sistem Pembuatan Starter MOCAF

\begin{tabular}{lllll}
\hline \multirow{2}{*}{ Metode } & \multicolumn{3}{c}{ Output } \\
\cline { 3 - 5 } Skala & Neraca Waktu & Neraca Energi & Neraca Biaya \\
Laboratorium & $\begin{array}{l}\text { Rochman } \\
(2015)\end{array}$ & $3-5$ hari & $\begin{array}{l}\text { Daya Listrik } \\
\text { Kapasitas } \\
\text { Laboratorium }\end{array}$ & Tinggi \\
\cline { 2 - 5 } & $\begin{array}{l}\text { Sulistiadi } \\
(2015)\end{array}$ & $\begin{array}{l}\text { Cepat } \\
\text { Langsung bisa } \\
\text { digunakan }\end{array}$ & $\begin{array}{l}\text { Kecil } \\
\text { Hanya transaksi } \\
\text { jual beli }\end{array}$ & $\begin{array}{l}\text { Rp 20.000,00 per 35 } \\
\text { ml. } \\
\text { Sangat Tinggi }\end{array}$ \\
\hline
\end{tabular}




\begin{tabular}{|c|c|c|c|c|}
\hline & \multirow{2}{*}{ Metode } & \multicolumn{3}{|c|}{ Output } \\
\hline & & Neraca Waktu & Neraca Energi & Neraca Biaya \\
\hline & $\begin{array}{l}\text { Sulistiadi } \\
(2012)\end{array}$ & 2 hari & $\begin{array}{l}\text { Kecil } \\
\text { Daya Listrik skala } \\
\text { rumah tangga }\end{array}$ & $\begin{array}{l}\text { Terjangkau } \\
\text { Hanya untuk sekali } \\
\text { pembelian }\end{array}$ \\
\hline \multirow{3}{*}{ Skala UKM } & Ragi Tape & 1 hari & $\begin{array}{l}\text { Kecil } \\
\text { Hanya transaksi } \\
\text { jual beli }\end{array}$ & $\begin{array}{l}\text { Mahal } \\
\text { Lebih Mahal dari } \\
\text { Singkong }\end{array}$ \\
\hline & $\begin{array}{l}\text { Dinas } \\
\text { Pemerintah }\end{array}$ & $\begin{array}{l}\text { Tidak Pasti } \\
\text { Menunggu } \\
\text { Pemberian }\end{array}$ & Kecil & $\begin{array}{l}\text { Mahal } \\
\text { Terbatas }\end{array}$ \\
\hline & Starter Online & $\begin{array}{l}\text { 5-7 hari } \\
\text { Menunggu } \\
\text { Pengiriman } \\
\text { Barang }\end{array}$ & Tinggi & $\begin{array}{l}\text { Tinggi } \\
\text { Rp } 20.000 \text { untuk } 100 \\
\text { mg }\end{array}$ \\
\hline
\end{tabular}

Berdasarkan Tabel. 1 dapat diketahui bahwa proses pembuatan starter BAL yang paling tepat diterapkan di Kabupaten Banyumas adalah metode pembuatan yang dilakukan oleh Sulistiadi (2012). Dalam neraca waktu pembuatan starter yang dilakukan oleh Sulistiadi (2012) hanya membutuhkan waktu selama 2 hari. Waktu yang dibutuhkan termasuk cepat jika dibandingkan dengan menggunakan metode skala laboratorium yang lain. Dalam perbandingan penggunaan energy pembuatan starter metode Sulistiadi(2012) memerlukan energy yang relative kecil dan dapat diterapkan diskala UKM karena daya listrik yang digunakan hanya skala rumah tangga. Kultur starter sebagai bibit starter yang digunakan juga dapat diperbaharui secara terus menerus sehingga modal yang digunakan dalam pembuatan starter sangat terjangkau.

Penyimpanan Bahan Baku Singkong, Pencacahan dan Fermentasi

Waktu sekitar 3 hari dengan energi dan biaya yang dibutuhkan terjangkau.
Sedangkan daya simpan Singkong menggunakan metode ini dapat bertahan dalam kondisi baik sampai 90 hari.

Metode Ginting (2002) juga menerapkan penyimpanan Singkong dengan menggunakan Fungisida dan Poliethilen sebagai komponen input yang dibutuhkan. Komponen proses dilakukan dengan langkah memasukkan Singkong ke dalam kantong plastik dengan bagian pangkal menghadap ke atas. Selanjutnya Singkong disemprot menggunakan Fungisida Mertec 450 EW. Neraca Waktu yang dibutuhkan sekitar 1 hari dengan energi yang dibutuhkan untuk memproses metode tersebut rendah. Sedangkan biaya yang dibutuhkan tinggi karena harga fungisida dan plastik cukup mahal. Metode penyimpanan ini mampu mempertahankan umur simpan Singkong selama 15 hari.

Skala UKM penyimpanan singkong yang dilakukan oleh petani Singkong, produsen MOCAF, dan penjual Singkong di pasar, dapat dibagi menjadi dua metode, yaitu Singkong yang dipanen langsung ketika ada pesanan dan Singkong yang 
dibiarkan tergeletak. Komponen output pada neraca waktu ini tergantung pada jumlah Singkong yang digunakan. Sedangkan pada neraca pembiayaan hanya bisa dilihat dari kebutuhan ruang atau tempat untuk menyimpan Singkong. Singkong setelah panen ketika dibiarkan hanya mampu bertahan selam 3 hari.

Proses pencacahan dan fermentasi Singkong merupakan rangkaian proses produksi yang terikat dengan jarak waktu yang sangat dekat. Teknologi pencacahan yang digunakan diketahui terdapat dua cara yaitu Singkong dicacah dalam bentuk sawut Singkong dan Singkong dicacah dalam bentuk chip Singkong. Proses pencacahan skala laboratorium menggunakan mesin pencacah Singkong dengan hasil bentuk chip Singkong seriping yang sudah banyak beredar di pasaran. Hasil analisis menunjukkan bahwa pada komponen output neraca waktu proses pencacahan dengan bentuk chip membutuhkan waktu selama dua hari sedangkan komponen pembiayaan yang dibutuhkan terjangkau karena alat mesin bisa didapatkan di pasaran dengan harga terjangkau. Proses pencacahan Singkong dalam bentuk sawut skala laboratorium melalui proses pemarutan dengan menggunakan mesin pemarut tenaga listrik yang juga bisa dengan mudah didapatkan di pasaran toko mesin pertanian.

Setelah proses pencacahan adalah proses fermentasi. Proses fermentasi dilakukan dengan melakukan perendaman pada singkong hasil pencacahan baik bentuk chip singkong atau sawut. Proses fermentasi tergantung dari pemilihan penggunaan starter bakteri. Fermentasi skala laboratorium menggunakan asam laktat praktis, diketahui hanya memerlukan waktu 1 jam. Sedangkan fermentasi menggunakan starter kacangkacangan dan air leri diketahui membutuhkan waktu selama 36 jam.

Pencacahan Singkong pada skala UKM dilakukan menggunakan cara manual dan semi otomatis. Cara manual dilakukan menggunakan parut tangan seriping Singkong untuk bentuk chip dan parut tangan getuk untuk bentuk sawut Singkong. Analisis pada komponen output untuk neraca waktu menunjukkan bahwa proses pencacahan Singkong membutuhkan waktu selama 2 hari. Sedangkan pada proses fermentasi neraca waktu pada komponen output menunjukkan lama waktu fermentasi rata-rata selama 24 jam. Tabel 2 menunjukkan hasil perbandingan neraca pada setiap metode pada proses penyimpanan dan pencacahan Singkong untuk MOCAF.

Tabel 2. Perbandingan Neraca Waktu dan Biaya pada Komponen Output Sub Sistem Penyimpanan dan Pencacahan MOCAF

\begin{tabular}{|c|c|c|c|c|}
\hline & \multirow{2}{*}{ Metode } & \multicolumn{3}{|c|}{ Output } \\
\hline & & Neraca Waktu & Neraca Biaya & Hasil \\
\hline $\begin{array}{l}\text { Skala } \\
\text { Laboratorium }\end{array}$ & $\begin{array}{l}\text { Singkong, } \\
\text { Jerami Lembab } \\
\text { (Ginting, 2002) }\end{array}$ & 3 hari & $\begin{array}{l}\text { Terjangkau } \\
\text { Membutuhkan ruang } \\
\text { simpan }\end{array}$ & $\begin{array}{l}\text { Umur simpan } \\
90 \text { hari }\end{array}$ \\
\hline
\end{tabular}




\begin{tabular}{|c|c|c|c|c|}
\hline & \multirow{2}{*}{ Metode } & \multicolumn{3}{|c|}{ Output } \\
\hline & & Neraca Waktu & Neraca Biaya & Hasil \\
\hline $\begin{array}{l}\text { Penyimpanan } \\
\text { Singkong }\end{array}$ & $\begin{array}{l}\text { Fungisida dan } \\
\text { Kemasan Plastik } \\
\text { Poliethilen } \\
\text { (Ginting, 2012) }\end{array}$ & 1 hari & $\begin{array}{l}\text { Tinggi } \\
\text { Item yang perlu dibeli } \\
\text { Fungisida, Poliethilen } \\
\text { Dan membutuhkan } \\
\text { ruang simpan }\end{array}$ & $\begin{array}{l}\text { Umur simpan } \\
15 \text { hari }\end{array}$ \\
\hline \multirow{2}{*}{$\begin{array}{l}\text { Skala UKM } \\
\text { Penyimpanan } \\
\text { Singkong }\end{array}$} & $\begin{array}{l}\text { Dipanen ketika } \\
\text { ada pesanan }\end{array}$ & $\begin{array}{l}\text { Cepat } \\
\text { Tergantung } \\
\text { kuantitas }\end{array}$ & Terjangkau & 3 hari \\
\hline & $\begin{array}{l}\text { Disimpan } \\
\text { dengan } \\
\text { dibiarkan saja }\end{array}$ & $\begin{array}{l}\text { Cepat } \\
\text { Tergantung } \\
\text { kuantitas } \\
\end{array}$ & Terjangkau & 3 hari \\
\hline \multirow{3}{*}{$\begin{array}{l}\text { Skala } \\
\text { Laboratorium } \\
\text { Pencacahan } \\
\text { Singkong }\end{array}$} & Bentuk Chip & Cepat & Mahal & Proses \\
\hline & Singkong & $\begin{array}{l}\text { Tergantung } \\
\text { kuantitas } \\
\text { menggunakan } \\
\text { mesin }\end{array}$ & $\begin{array}{l}\text { Biaya penggunaan } \\
\text { Laboratorium }\end{array}$ & $\begin{array}{l}\text { pengolahan } \\
\text { selanjutnya } \\
\text { mudah }\end{array}$ \\
\hline & $\begin{array}{l}\text { Bentuk Sawut } \\
\text { Singkong }\end{array}$ & $\begin{array}{l}\text { Cepat } \\
\text { Tergantung } \\
\text { kuantitas } \\
\text { menggunakan } \\
\text { mesin }\end{array}$ & $\begin{array}{l}\text { Mahal } \\
\text { Biaya Penggunaan } \\
\text { Laboratorium }\end{array}$ & $\begin{array}{l}\text { Proses } \\
\text { pengolahan } \\
\text { selanjutnya } \\
\text { panjang }\end{array}$ \\
\hline \multirow[t]{2}{*}{$\begin{array}{l}\text { Skala UKM } \\
\text { Pencacahan } \\
\text { Singkong }\end{array}$} & $\begin{array}{l}\text { Parut tangan } \\
\text { Seriping }\end{array}$ & $\begin{array}{l}\text { Cepat } \\
\text { Tergantung } \\
\text { kuantitas } \\
\end{array}$ & Terjangkau & Bentuk Chip \\
\hline & $\begin{array}{l}\text { Parut Tangan } \\
\text { Getuk }\end{array}$ & $\begin{array}{l}\text { Cepat } \\
\text { Tergantung } \\
\text { kuantitas }\end{array}$ & Terjangkau & $\begin{array}{l}\text { Bentuk } \\
\text { Sawut }\end{array}$ \\
\hline
\end{tabular}

Berdasarkan Tabel 1.2 teknologi proses penyimpanan Singkong yang dapat diterapkan di Banyumas adalah dengan bahan jerami lembab yang mampu mempertahankan umur simpan Singkong mencapai 90 hari dengan pembiayaan yang terjangkau dan waktu yang dibutuhkan termasuk singkat. Sedangkan teknologi pencacahan yang dapat diterapkan di Banyumas dengan menggunakan mesin seriping. Penggunaan mesin pemotong seriping singkong hanya membutuhkan waktu yang sedikit dan mesin serta suku cadang yang digunakan sangat mudah didapatkan sekalipun berada di wilayah pedesaan dan kota kecil.

\section{SIMPULAN}

1. Teknologi proses yang paling tepat dapat diterapkan dalam pembuatan starter BAL adalah menggunakan kacang-kacangan dan air leri sebagai bahan untuk memfermentasi Singkong menjadi MOCAF.

2. Teknologi proses penyimpanan Singkong yang dapat diterapkan di Banyumas adalah dengan bahan jerami lembab yang mampu mempertahankan umur simpan Singkong mencapai 90 hari, sedangkan pencacahan yang dapat diterapkan di Banyumas dengan menggunkan mesin seriping dan teknologi fermentasi dapat 
dilakukan dengan menggunakan BAL yang bersalah dari starter air leri dan kacang-kacangan.

\section{DAFTAR PUSTAKA}

Alocilja E. 2008. Principles of Biosystems Engineering. Michigan. $4 \mathrm{pp}$.

Ermiza M. 2011. Substitusi Tepung Kimpul Pada Pembuatan Kue Bulan Sebagai Sumber Serat Dan Alternatif Pengganti Tepung Terigu. Universitas Negeri Yogyakarta: Yogyakarta.

Ginting E. 2002. Teknologi Penanganna Pascapanen dan Pengolahan Ubikayu Menjadi Produk-Antara untuk Mendukung Agroindustri. Bul. Palawija 4:67-83

Handayani I, Mustaufik. 2006. Penggunaan Campuran Bakteri Asam Lkatat dan Khamir sebagai Flavouring Agent pada Sari Buah Mengkudu Terfermentasi.Jurnal

Pembangunan Pedesaan 6(3):133142

Jading A, Eduard T, Paulus P, Sarman G. 2011. Karakteristik Fisikokimia Pati Sagu Hasil Pengeringan Secara Fluidisasi Menggunakan Alat Pengering Cross Flow Fluidized Bed Bertenaga Surya dan Biomassa Reaktor, Vol. 13 No. 3, Juni 2011, Hal. 155-164

Meliani V. 2002. Skripsi, Mempelajari Penggunaan Tepung Sukun (Artocarpus altilis (Park.) Fsb) Sebagai Bahan Substitusi Tepung Terigu Dalam Pembuatan Cookies. Institut Pertanian Bogor: Bogor.

Pangloli., Rojangsih. 1998. Pembuatan Mie Basah dari Campuran Terigu dan Tepung Sagu [Prosiding Seminar Penelitian]. Badan Litbang Pertanian: Bogor.
Prabandari A. 2008. Skripsi Komparasi Uji Karbohidrat Pada Produk Olahan Makanan Dari Tepung Terigu Dan Tepung Biji Nangka (Artocarpus heterophyllus). Fakultas Keguruan Dan IImu Pendidikan Universitas Muhammadiyah Surakarta: Surakarta

Rachman SD, Djajasoepena S, Kamara DS, Idar I, Sutrisna R, Safari A, Suprijana O, Ishmayana S. 2015. Kualitas Yoghurt yang dibuat dengan Kultur Dua (Lactobacillus bulgaricus dan Streptococcus thermophilus) dan Tiga Bakteri (Lactobacillus bulgaricus, Streptococcus thermophilus DAN Lactobacillus acidophilus). Chimica et Natura Acta 3 (2):76-79

Ridha A, Afsari MD. 2016. Profil Komoditas Barang Kebutuhan Pokok dan Barang Penting Komoditas Tepung Terigu. Jakarta. 25 pp.

Suarni. 2004. Pemanfaatan Tepung Sorgum untuk Produk Olahan. Balai Penelitian Tanaman Serealia Makasar: Makasar.

Subagio A. 2007. Industrialisasi Modified Cassava Flour (MOCAL) Sebagai Bahan Baku Industri Pangan Untuk Menunjang Diversifikasi Pangan Pokok Nasional. Tidak Diterbitkan. Fakultas Teknologi Pertanian. Universitas Jember: Jember.

Sulistiadi, S. 2015. Pengaruh Variasi Kosentrasi Hidrogen Peroksida (H2O2) dan Lama Penyinaran UVC terhadap Perubahan Sifat Fisikokimia Tepung Kasava [Tesis]. Universitas Gadjah Mada Yogyakarta: Yogyakarta.

Sulistiadi SD, Mulyadianto, Maslikan. 2012. Industri MOCAF Berbasis Teknologi Kearifan Lokal Menggunakan Inkubator Keramik Tanah sebagai Media Fermentasi di Kabupaten Banyumas. Juara Kompetisi Technopreneurship Pemuda. Kemenristek: Jakarta. 